\title{
Adoption and Use of Information Communication Technologies in Zimbabwean Supermarkets
}

\author{
Cinderella Dube ${ }^{1} \&$ Victor Gumbo ${ }^{2}$ \\ ${ }^{1}$ Research and Innovation Office, National University of Science and Technology, Bulawayo, Zimbabwe. \\ ${ }^{2}$ Department of Mathematics, Faculty of Science, University of Namibia, Windhoek, Namibia. \\ Correspondence: Cinderella Dube, Research and Innovation Office, National University of Science and Technology, \\ Bulawayo, Zimbabwe.
}

Received: September 4, 2016

Accepted: September 29, $2016 \quad$ Available online: October 24, 2016

doi:10.11114/aef.v4i1.1860

URL: http://dx.doi.org/10.11114/aef.v4i1.1860

\begin{abstract}
The use of computers and technology has become vital for any organisation to survive in this digital era. The adoption and use of Information and Communication Technologies (ICTs) in supermarkets has been accepted, particularly, in developed countries. However, there has been little information on the adoption and use of ICTs in supermarkets in Zimbabwe as a whole. Therefore, the main objective of this study was to explore the rate of adoption and use of ICTs in Zimbabwean supermarkets and to measure their impact. The study also sought to suggest measures that supermarkets could take in an effort to overcome the challenges faced in the use of ICTs in grocery shopping in Zimbabwe. The results were interpreted using the Keynesian Theory of Money and they revealed that all supermarkets had adopted Point of Sale (POS) and few of them had adopted mobile money. The majority of the customers however still preferred to transact using cash. The study also showed that the greatest benefits of online transactions were convenience, high customer retention, and increased efficiency whereas the greatest challenges were network connection problems and poor adoption by customers. The study urged customers to adopt and use online ICTs in supermarkets in order to take advantage of their benefits. The study also recommended supermarkets and the government to take heed of the measures suggested by the respondents in order to avert the adverse consequences of the challenges faced in the use of ICTs.
\end{abstract}

Keywords: Information and Communication Technologies, Adoption, Use, Point of Sale, Mobile money, Keynesian Theory of Money

\section{Introduction}

Over the past few years, Zimbabwe has experienced considerable economic recovery due to the demonetisation of the Zimbabwean dollar and the adoption of multi currencies in 2009, with the United States dollar being the most widely used currency (Jefferis, Chigumira \& Chipumho, 2013). Despite these achievements, the economy is still facing some challenges which are largely mirrored by the macro-economic constraints in the country. Some of the challenges include the liquidity crunch, lack of capital inflow, lack of production in the country as well as the high cost of doing business. The liquidity crisis is characterised by shortages of cash due to lack of access and high cost of finance and money in circulation is too limited to meet the demands of an economy that is struggling to strive (Confederation of Zimbabwean Industries Report, 2014). In order to resolve these problems, the Zimbabwean business sector has been urged to embrace the use of ICTs which enhance online transactions rather than cash transactions.

Research on ICTs reveals that the acceptance of online grocery buying by consumers has been rapid in many parts of the world, and in the leading e-banking countries the number of e-banking contracts has exceeded 50 percent (Pikkarainen, Pikkarainen, Karjaluoto \& Pahnila, 2004). There has been little information on acceptance of ICTs in Zimbabwe, particularly in supermarkets, hence the purpose of this study is to address the literature gap in the field of ICTs in Zimbabwe. Although Shambare (2013) studied POS Systems in Zimbabwe, the researcher ignored the use of Mobile money. Therefore this research took a holistic approach in that both POS and Mobile money in supermarkets were studied. The advantage of studying these ICTs together was that it facilitated a comparison of their adoption and use since the same samples were used. 
The purpose of this research was therefore to explore the extent to which supermarkets in Zimbabwe have adopted and used POS and Mobile money platforms. The study also sought to find out the impact of these ICTs on the supermarkets that use them. The study also explored measures that could be used to overcome the challenges identified by the participants. The study went on to explain the situation using the Keynesian Theory of Money.

\section{Review of Literature}

\subsection{Information Communication Technologies}

The use of computers and technology today has become fundamental to the operation of organisations and society (Yonck, 2010). Thus, ICTs have demonstrated capabilities to encompass potential innovations which enable their use to the benefit of the organisations and society as a whole. Information is carried and processed at great speeds within and across a variety of communication networks allowing the transfer of enormous amounts of information in real-time through a matrix of networks (Hansnaoui \& Freeman, 2010). This increasing global penetration of ICTs enabled by the Internet has also reached the retail industry, particularly the buying of groceries in supermarkets. ICTs can be defined as a combination of technologies that provide access to information through telecommunications which have the capacity to capture, transmit and display data and information electronically (Organisation for Economic Co-operation and Development, 2002). These include the Internet, wireless networks, radio, television, cell phones, computer and network hardware and software, satellite systems and other communication mediums (Olatokun, 2011). Hence in this study, ICTs refer to the POS systems and cell phones that are used to perform online transactions such as buying groceries in supermarkets.

\subsection{Online Transactions}

An online transaction is a computerised monetary transaction and is a password-protected method of transferring funds remotely from one technology to another (Gilbert \& Hewitt, 2013; Meerapur, 2014). In supermarkets, an online transaction is initiated at a POS and automatically processes monetary transfer from the customer's bank account to the POS once it is authenticated by the customer through their PIN (Personal Identification Number). A Point of Sale is the point at which a customer makes a payment to the merchant in exchange for goods or services (Bernardo, 2013). An electronic payment system can be self-contained in that a customer can buy goods at a self-checkout counter using their Automated Teller Machines (ATM) cards without the assistance of a supermarket employee or one can make a payment with the assistance of the merchant (Tyler, 2007; Padoa- Schioppa, 2003). In Zimbabwe, the latter is most prevalent in supermarkets where the customer takes their products to a cashier who swipes their ATM card in the card reader. The POS terminal checks the card's validity, connects to the bank that issued the card and once the payment has been credited to the account, it prints out a receipt to the customer (Rouse, 2011). In Zimbabwe, using POS to buy groceries is made convenient by the use of the ZimSwitch platform whereby customers can accesses their bank accounts for paying for groceries through a single point if their bank has partnered with ZimSwitch. ZimSwitch is an online transacting company owned by ZimSwitch Technologies and is the sole national electronic funds switch for Zimbabwe (ZimSwitch Technologies, 2013).

Mobile money is defined by Ernst and Young (2009) as a service that allows electronic money transfer via a mobile phone. Mobile money is cash-based in that the user needs to deposit money into their account. In this study, on-site person-to-business mobile money transfers were considered (Ernst \& Young, 2009). For a mobile money transaction to take place, there is need for collaboration between the Mobile Network Operator (MNO), Mobile Money Operator (MMO), the supermarket and the customer (Jenkins, 2008). In this respect, the mobile money transfer is initiated by the customer and the money transfer is acknowledged by the supermarket till operator.

In Zimbabwe, the major MNOs are NetOne, Telecel Zimbabwe and Econet Wireless Zimbabwe. They all use pre-paid tariffs. By the end of 2014, the estimated mobile penetration had reached 128\% (Lancaster and Lange: 2015). The MNOs also own the MMOs. By mid-2014, Econet's Ecocash had 3.5 million subscribers translating to $81 \%$ of the market share, Telecel's Telecash had over 600000 subscribers (14\% of the market share) and NetOne's OneWallet had 200000 subscribers translating to 5\% of the market share (Kabweza, 2014).

Research on the use of mobile money in Zimbabwe indicated that mobile money enhances financial inclusion which enables the poor to transact online without having to meet banking requirements needed by banks (Munyanyi, 2014). Research has also revealed some of the benefits of POS and Mobile money such as reduction of transitory cash in the economy, improved profitability, reduced risk, faster settlement, low charges and better customer services, accessibility (proximity) and liquidity management among others (Greene, Rysman, Schuh and Shy (2014) in the United States of America (USA); Marsden (2013) in the United Kingdom; Adeoti and Oshotimehin (2011) in Nigeria, Dzokoto and Appiah (2014) in Ghana and Kufandirimbwa, Zanamwe, Hapanyengwi and Kabana (2013) in Zimbabwe. Some of the challenges of POS identified by Nwankwo and Eke (2013) in Nigeria are network reliability, fraud, security, online charges, security threat, system stability, poor uptake, literacy issues, frequent power outage, limited numbers of POS 
per merchant store where they are available, unavailability of the POS in stores (Adeoti, 2013).

\subsection{Theoretical Frameworks}

This study is influenced by the Keynesian Theory of Money (also known as the Liquidity Preference Theory) which was developed by the Economist, John Maynard Keynes. As explained by Amir (2011) and Ishad (2014), in Keynesian theory, cash money is called liquidity and the liking of cash by people is called liquidity Preference. According to Keynes people demand liquidity or prefer cash because they have three different motives. These motives, he termed, transaction motive, precaution motive and speculative motive. The transactional motive is described as people's need for cash to purchase commodities to satisfy day-to-day needs like food and housing. The precautionary motive refers to the desire to hold cash for unforeseen events. Thus individuals hold cash to provide for contingencies like illness, accidents and unemployment. The speculative motive for cash arises when the transactional and precautionary demand for money are satisfied. Cash is thus held to take advantage of future changes in the rate of interests (if they go up, individuals sell) or bond prices (when they go down, individuals buy more). According to Keynes, a liquidity trap is a situation where interest rates have dropped down to zero or next to zero. Basically, people and businesses hold on to their cash and the economy is consequently trapped in a situation where people are not depositing their money in banks and banks are not giving loans to individuals/companies because the loans perform poorly despite an injection of money into the banks, for example, by a central bank.

\subsection{Liquidity Preference Theory and the Zimbabwean Situation}

After the collapse of the banking system in 2008, people have had little trust in the financial system leading to low deposits and this accounted for the slow growth in the financial sector (Gumbo \& Zoromedza, 2016). This is also aggravated by the fact that there is a high unemployment rate with $89 \%$ employed in the informal sector. Of these, about 52\% earn less than $\$ 100.00$ a month whilst more than 55\% of the formally employed earned about $\$ 500.00$. Only about 3\% of the formally employed earn more than $\$ 1000.00$ and less than $1 \%$ of the informally employed earn more than $\$ 1000.00$ a month (Saungweme, Matsvai \& Sakuhuni, 2014). The Governor of the Reserve Bank of Zimbabwe stated that the Poverty Datum Line (PDL) for Zimbabwe was too high at $\$ 502.90$ for a family of 5 which translated to $\$ 100.58$ for an individual per month (Macheka, 2014). He was comparing it with those of neighbouring countries, such as, South Africa at $\$ 52.40$, Botswana at $\$ 53.44$ and Malawi at $\$ 80.00$ in December 2013. The Consumer Council of Zimbabwe also announced that the bread basket for a family of six was $\$ 559.97$ in 2014, which was quite high (The Daily News, 2014). Given the above scenario, with respect to the liquidity preference theory, people consequently use their incomes for the transactional motive more than the precautionary and speculative motive.

\section{Method}

The study took a mixed method approach which was qualitative-led. Mixed methods research uses both qualitative and quantitative data either simultaneously or sequentially to best suit the research problems (Johnson, Onwuegbuzie \& Turner, 2007). In this research, data collection was done simultaneously whereby questionnaires were distributed and interviews were conducted concurrently. The exploratory case study design was chosen because the study sought to collect data in its natural settings since the area of study is relatively new (Denscombe, 2004). In this research, the case was limited to supermarkets that sell groceries. Hence retail outlets like furniture and clothing stores were excluded.

The target population included supermarkets located countrywide in Zimbabwe and the study population comprised of 59 OK Zimbabwe Supermarkets, 50 TM Zimbabwe Supermarkets and 74 Spar Supermarkets located in Harare (OK Zimbabwe, 2015; TM Zimbabwe 2014, SPAR Zimbabwe, 2015). Harare was chosen because most head offices of these supermarkets were located in Harare and therefore the views of the participants were presumed to encompass the views of their respective stores countrywide. Non-probability sampling methods were used. These were convenience sampling in selecting supermarket customers; purposive sampling in selecting supermarket employees/managers (questionnaire respondents) and snowball sampling in selecting employees/managers (interviewees). The final sample consisted of 268 customers, 31 questionnaire respondents and 4 interviewees. In this study employee respondents to questionnaires were referred to as managers in order to distinguish them from interviewees, although they were all managers in some respect. Open and close-ended questionnaires were used to collect data from customers and managers and semi-structured interview guides were used for the interviews.

\section{Results}

A total of 400 questionnaires were distributed to supermarket customers and 268 were returned giving a return rate of $67 \%$. Of these $57 \%$ were male and $43 \%$ were female. The majority of the respondents were between the ages of $31-40$ $(56 \%)$ followed by those below the age of $30(35 \%)$ and those between $41-50$ years (8\%). The least age group was made up of those between $51-60$ years of age (1\%). A total of 45 questionnaires were distributed to supermarket employees (Managers) and 31 were returned giving a return rate of $68.9 \%$. The majority of the participants consisted of Till Operation Managers (26\%) followed by Branch Accounting Managers (16\%), ICT Managers (16\%), Assistant 
Managers (13\%), Branch Managers (10\%). Others (19\%) did not fit into the given categories. Four interviews were conducted of which 2 of the interviewees were male while 2 were female. The interviewees consisted of 3 ICT Managers and 1 Financial Manager. The questionnaires were analysed using Statistical Package for the Social Sciences (SPSS) version 20 and the interviews were analysed using Nvivo 11 software for qualitative data.

\subsection{Adoption and Use}

The data on the adoption and use of ICTs in supermarkets was analysed and grouped in terms of the views of customers, managers who responded to questionnaires and managers who were interviewed.

\subsubsection{Customers}

The majority of supermarket customers (96\%) had ATM cards and all the respondents owned a cellular phone. The majority of them owned one mobile handset (51\%), followed by $39 \%$ who owned two handsets and $10 \%$ who owned 3 handsets respectively. Ninety percent of the customers had registered for mobile money and $10 \%$ had not registered for any of the mobile money platforms. Of those who had registered for mobile money, the majority of them had registered for Ecocash (80\%) followed by Telecash (8\%) and OneWallet (2\%) respectively.

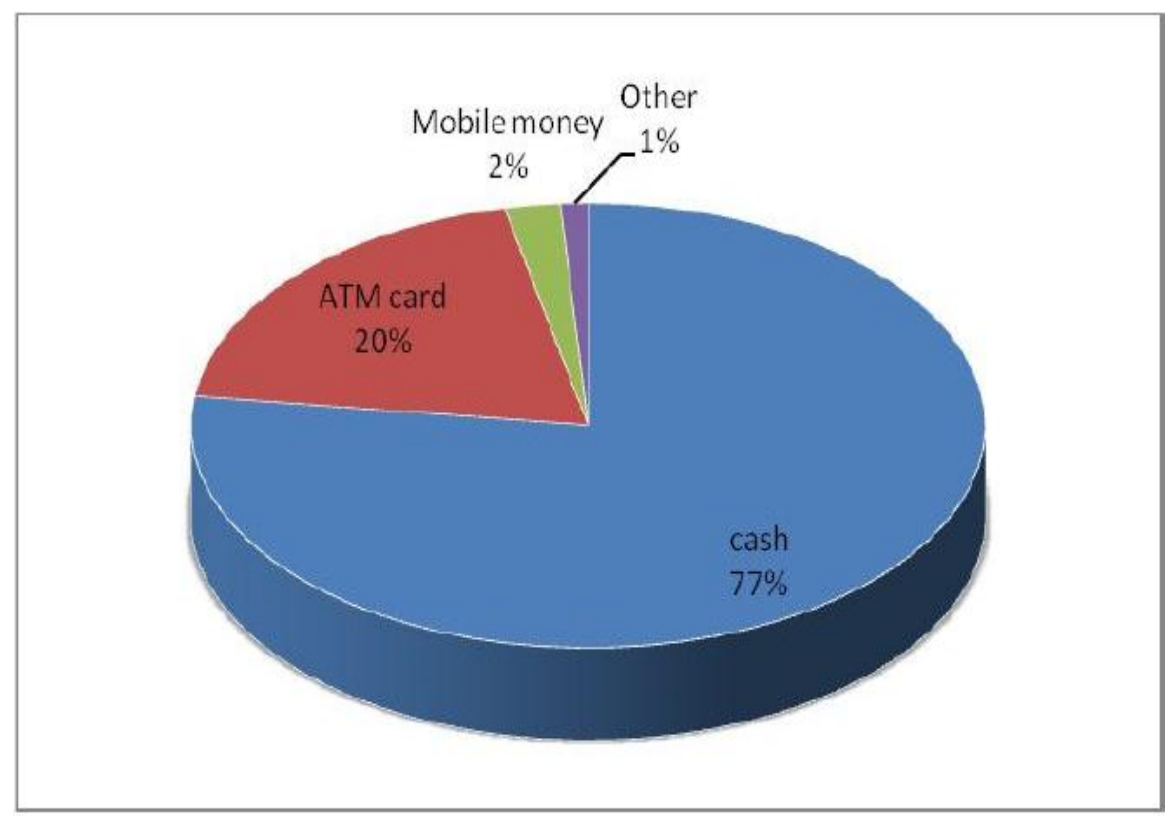

Figure 1. Preferred Mode of Payment When Buying from A Supermarket

With respect to the adoption of online transactions, the majority of customers (77\%) used cash as their preferred mode of paying for their groceries in supermarket, followed by $20 \%$ who used the ATM cards (POS), $2 \%$ who used Mobile money and $1 \%$ who used other modes of payments as shown in Figure 1. A cross tabulation analysis was computed between preferred mode of payment for groceries in Supermarkets and gender. The results indicated that more females $(82 \%)$ used cash than males $(74 \%)$ whereas more males $(21 \%)$ used ATM cards (POS) than females (17\%). Mobile money was also used mainly by males (3\%) as compared to females $(1 \%)$. On the whole, the majority of males and females preferred using cash than online transactions. When asked whether they would deposit money in their bank accounts if they were given US\$1000.00, the majority (63\%) of the customers indicated that they would not. They gave the need to use the money immediately and uncertainty of bank's sustainability as some of the reasons for not depositing the money in their bank accounts.

Overall, after computing the average percentages of the services that were always and sometimes used, the results indicated that the most frequently used POS services included buying groceries, cash back, and balance enquiry. The most frequently used mobile money services were to send money, cash-out and airtime top-up. When asked how often they used their ATM cards at the POS to buy groceries, the results indicated that some of the respondents used them once a month (14\%) followed by those who used them twice a month (9\%), $1-3$ times a week (9\%). However the majority of the customers never used (35\%) or rarely used 33\% their ATM cards for buying groceries.

\subsubsection{Supermarket Managers}

All the managers (100\%) who responded through questionnaires indicated that their supermarkets had adopted POS and $26 \%$ indicated that their customers could use mobile money to buy groceries. When asked how long their supermarkets had been using POS, the majority (36\%) of the respondents indicated that POS had been used for 5 years and below 
followed by $28 \%$ who indicated that POS had been used for between $6-10$ years respectively. Few respondents (14\%) showed that POS had been used for between $11-15$ years followed by $11 \%$ who used them for $16-20$ years and $11 \%$ who used them for over 20 years. The respondents were asked how many branches operated POS machines in Zimbabwe and all of them indicated that all their branches operated POS. When asked how many POS machines were installed in each branch, the majority of the respondents (42\%) indicated that their branches had between $6-15$ machines, followed by those (39\%) who said their branches had 5 machines and below. A few (19\%) branches had over 15 machines.

When asked what percentage of their customers used POS, the majority (42\%) of the respondents indicated that most of their customers used less than 20\% of POS services, followed by $29 \%$ who said their customers used $21-40 \%$ and $19 \%$ who said their customers used over $70 \%$ of the POS services respectively. Very few $(6 \%)$ of the respondents indicated that their customers used $41-50 \%$ and $4 \%$ indicated that their customers used $61 \%-70 \%$ of POS services. The respondents were asked what percentage volume of revenue was brought to their supermarkets through the use of POS as compared to revenue brought in through cash. The majority of the respondents $(47 \%)$ indicated that very little volume (less than 20\%) was brought into the supermarket through POS followed by $30 \%$ who showed that $21-40 \%$ was brought in through POS. Few (10\%) respondents believed that customers brought in over $70 \%$ of revenue followed by $7 \%$ who indicated that $61-701 \%$ volume of revenue was brought in through POS. Very few (3\%) respondents indicated that $41-50 \%$ of the revenue was brought in through POS and another 3\% indicated that $51-60 \%$ revenue was brought into the supermarkets as compared to cash payments respectively.

\subsubsection{Supermarket Interviewees}

All the interviewees indicated that their supermarkets had adopted POS and one (1) had adopted mobile money- All the respondents also indicated that all their branches in Zimbabwe used POS machines. Interviewees were asked on average, what percentage of their customers used POS services and the percentages given ranged from $11 \%$ to $20 \%$, giving an average of $14.5 \%$. When asked what percentage volume of their supermarket's revenue was brought in through customers paying through POS as compared to cash paying customers, the responses ranged from $5-20 \%$ giving an average of $12.5 \%$. All the interviewees said that buying groceries and cash withdrawal (cash-back) were the main POS services used by customers followed by balance enquiry and cash deposits (identified by half the respondents). One (1) respondent identified bill payments as another service used by their customers.

\subsection{Impact of ICTs in Supermarkets}

The impact of online transactions was measured through the benefits and challenges of online transactions to the customer and the organisation. Table 1 and Table 2 show the results of the combined averages of those who strongly agreed and those who agreed on the benefits and challenges of adopting and using ICTs in supermarkets on a 5-point likert scale

Table 1. Benefits of ICTs in Supermarkets

\begin{tabular}{lll}
\hline Customers' Views & Managers' Views & Interviewees' Views \\
\hline Convenience (92\%) & High customer retention (57\%) & Efficiency (100\%) \\
Accessibility (88\%) & Increased efficiency (45.5\%) & Time saving (100\%) \\
Better accounting of funds (72\%) & High accessibility (43.5\%) & Convenience (75\%) \\
Low error incidents (65\%) & High reliability (40\%) & Cost reduction (50\%) \\
Low transactions charges (64\%) & Saves on transaction time (38.5\%) & Theft reduction (50\%) \\
& Cost reduction (37\%) & Profitability (25\%) \\
& Increased customer base (32.5\%) & \\
& Reduces queues in supermarkets (24\%) & \\
& Development of non-core business (24\%) & \\
\hline
\end{tabular}

Table 1 shows that the greatest benefits of using ICTs in grocery shopping as identified by customers were convenience, accessibility and better accounting of funds among others. Managers identified the greatest benefits as high customer retention, increased efficiency and high accessibility among others. Interviewees, on the other hand, identified efficiency, time saving and convenience among others as the greatest benefits of using ICTs in supermarkets. 
Table 2. Challenges of ICTs in Supermarkets

\begin{tabular}{lll}
\hline Customers' Views & Managers' Views & Interviewees' Views \\
\hline Poor network connectivity (78\%) & Network connection problems (46.5\%) & $\begin{array}{l}\text { Poor network connectivity } \\
(100 \%)\end{array}$ \\
$\begin{array}{ll}\text { Systems malfunctioning (77\%) } \\
\text { Poor response to complaints }\end{array}$ & $\begin{array}{l}\text { Poor adoption by customers }(38.5 \%) \\
\text { High initial costs (37\%) }\end{array}$ & $\begin{array}{l}\text { High initial costs (100\%) } \\
\text { Poor adoption by customers } \\
(71 \%)\end{array}$ \\
Security issues (61\%) & Mistrust by customers (35\%) & Security issues (50\%) \\
& Lack of expertise (31\%) & Systems malfunction (50\%) \\
& Lack of systems compatibility (26.5\%) & \\
& Security issues (25\%) & \\
\hline & High transactional charges (19\%) & \\
\hline
\end{tabular}

Table 2 shows that the greatest challenges in using ICTs in grocery shopping as identified by customers were poor network connectivity, systems malfunctioning and poor response to complaints. Managers identified the greatest challenges as systems network connectivity problems, poor adoption by customers and high initial costs among others. Interviewees identified poor network connectivity, high initial costs and poor adoption by customers among others challenges.

Customers were asked what measures they thought supermarkets should take to improve buying of groceries using ICTs in supermarkets. The majority (53\%) of the customers indicated that there was need for improved network connectivity followed by increasing POS points (18\%), upgrading equipment (9\%), providing information to customers frequently (9\%), reducing transactional costs $(8 \%)$ and others (3\%). Managers were also asked what measures their respective supermarkets could take to improve online buying of groceries in an effort to attract more customers. The majority (29\%) of the respondents indicated that there was need for introducing more POS machines in supermarkets followed by adopting their own online payment systems (22\%), preparing for other payment systems (21\%), advertising (14\%), advocating for reduced POS charges (7\%) and adopting mobile money payment systems (7\%). Interviewees were asked what measures their supermarkets were taking in preparation for a cashless society and respondents indicated that they were in the process of developing platforms to enable online shopping by POS, enabling the use of Visa/Master cards, eBay, credit cards and developing their own personalised platforms. Other respondents said that their supermarkets were working together with Mobile Network Operators to enable buying of groceries using mobile phones and lobbying for RBZ to legislate online grocery buying.

\section{Discussion}

The findings indicate that all supermarkets had adopted and were using POS. Despite the fact that mobile penetration was over $100 \%$ and that the majority (96\%), of customers had ATM cards the adoption of POS by customers was still very low (20\% by managers and 1 interviewee). This could be explained by the fact that people use their money for the transactional motive in cash as indicated by $77 \%$ (in Figure 1) of the customers who used cash as they needed to use it immediately without having to put it in the bank first. With reference to supermarket employees, the adoption rate of mobile money was only $25.5 \%$ (mean derived from $26 \%$ from questionnaires and $25 \%$ from interviews). However, the customers had the capacity to buy groceries using mobile money since $90 \%$ of them were registered for mobile money but may not have the cash to deposit into their mobile wallets due to the transactional motive.

The adoption rate for supermarket customers was $20 \%$ for POS and $2 \%$ for Mobile money giving an average adoption rate of $11 \%$. Therefore, according to the Maturity Model Adoption Curve, mobile money can be said to be in its prenatal stage and POS can be said to be in its infancy stage (Rogers, 1995; Eckerson, 2009). With respect to Roger's Adoption categories, Zimbabwean supermarkets have managed to capture the innovators and early adopters for POS at $20 \%$ market penetration and only the innovators at $2 \%$ market penetration for mobile money (Rogers, 1995, Johnston, 2011). Of those who used POS, the most frequently used services were buying groceries, cash back, and balance enquiries. However the rate of use was mostly once a month. This could be because salaries in Zimbabwe are mostly paid once monthly, hence customers may only be able to buy their groceries once a month in relation to their pay days. Although supermarkets had made efforts to install many POS machines in their stores, the volume of revenue brought in by ICTs was still low (less than $20 \%$ by managers and $12.5 \%$ by interviewees). 
Given the scenario of the low incomes, the high Poverty Datum Line and high bread basket discussed is in Section 2.4, Zimbabwe is in a situation where people would rather use their income for basic needs like food, shelter and clothing instead of depositing it in banks for future POS use in line with Maslow's hierarchy of needs where only when the physiological needs are met, will people seek the next order of needs (Jerome, 2013). With respect to buying groceries, using POS and Mobile money, would be difficult in a liquidity crisis environment since their use depended on cash being previously deposited in the customers' bank accounts or mobile wallets. This is also supported by the fact that when asked whether they would deposit money in their bank accounts if they were given US $\$ 1000.00$, the majority $(63 \%)$ of respondents indicated that they would not. They gave the need to use the money immediately and uncertainty of bank's sustainability as some of the reasons for not depositing money in banks. In this respect, poor adoption, mistrust by customers and security issues (shown in Table 2) were identified as challenges to ICTs in supermarkets by both Managers and interviewees and supported by Nwankwo and Eke (2013) and Adeoti (2013).

The advantages of ICTs are mostly felt in liquidity crisis/trap situations (as in the current Zimbabwean situation) where the amount of money in circulation is less than that which banks need to meet withdrawal demands by customers. In scenarios where salaries are paid via Real Time Gross Settlement (RTGS) or via Mobile money, customers can thus buy groceries using POS or mobile money without the need to withdraw cash from their bank first. The benefits like convenience, accessibility and efficiency which are shown in Table 1 then come into play.

ICTs in supermarkets are a gateway leading to the future cashless society. Based on the conclusions in this study, customers are advised to adopt and use online ICTs in supermarkets in order to take advantage of the benefits of using them. Supermarkets are urged to increase awareness initiatives in order to avail information to customers to enhance adoption and use of these ICTs. Supermarkets are also urged to develop platforms to enable online buying through the use of Visa/Master cards, eBay and credit cards in preparation for grocery buying in a cashless society.

The government is urged to make more efforts to improve productivity in order to improve bankability of customers which will increase bank deposits that enable customers to use ICTs in supermarkets. At the same time the Reserve Bank of Zimbabwe is urged to put measures in place to improve interoperability between banks, MNOs, MMOs and supermarkets to enhance Financial Inclusion in Zimbabwe. Internet service providers are recommended to provide quality internet connectivity in order to mitigate some of the challenges of using POS and mobile money in Zimbabwe. Although the results can be considered statistically significant, they pose a limitation in that they are representative, to a large extent, to the study population. However, in terms of representation in case studies, transferability to the rest of Supermarkets in Zimbabwe is possible due to the replicability and/or reliability of results obtained in the two samples of the study (Tashakkori \& Teddlie, 2003). Nevertheless, it is hoped that the results of this study will be used as a foundation for further studies. The uptake of ICTs in other organisations in Zimbabwe, the Diaspora and International countries could be studied.

\section{Acknowledgements}

The authors express their gratitude to the National University of Science and Technology Research Board for providing funding for this study.

\section{References}

Adeoti, O. O., \& Oshotimehin, K. O. (2011). Factors Influencing Consumers Adoption of Point of Sale Terminals in Nigeria. Journal of Emerging Trends in Economics and Management Sciences, 2(5), 388-392. Retrieved from http://jetems.scholarlinkresearch.com/articles/Factors\%20Influencing\%20Consumers.pdf.

Adeoti, O. O. (2013). Challenges to the efficient use of point of sale (POS) terminals in Nigeria. African Journal of Business Management, 7(28), 2801-2806. Retrieved from http://www.academicjournals.org/journal/AJBM/article-abstract/D3BCA5939442.

Amir, S. (2011). The Liquidity Preference Theory. Retrieved from http://www.tutors2u.com/rte/File/Economics/LIQUIDITY\%20PREFERENCE\%20THEORY.pdf.

Bernardo, M. (2013). Point of Sale. Retrieved from http://www.slideshare.net/yuri56/point-of-sale-29179086.

Confederation of Zimbabwe Industries (2014). 2014 CZI Manufacturing Sector Survey Report. Retrieved from http://www.czi.co.zw/images/Presentations/2014.pdf.

Denscombe, M. (2004). The Good Research Guide for small-scale social research (2nd ed.). Maidenhead: McGraw Hill Open University Press.

Dzokoto, V. A., \& Appiah, E. (2014). Making Sense of Mobile Money. In Urban Ghana: Personal, Business, Social and Financial Inclusion Prospects. Department of African American Studies Research: Virginia Commonwealth University. Retrieved from http://www.imtfi.uci.edu/files/docs/2014/dzkoto_final_report_feb2014.pdf. 
Eckerson, W. (2009). Maturity Model Adoption Curve - Six Stages. The Data Warehousing Institute: Education and Research. Retrieved from http://www.eurim.org.uk/activities/ig/voi/03-01-06_Executive_Series_Assessing_Your_BI_Maturity.pdf.

Ernst, \& Young, E. (2009). Mobile Money: An overview for global telecommunications operators. Retrieved from http://www.ey.com/Publication/vwLUAssets/Mobile_Money./\$FILE/Ernst \& Young - Mobile Money.

Gilbert, L., \& Hewitt, J. (2013). Online Transaction Processing. Retrieved from http://searchdatacenter.techtarget.com/definition/OLTP.

Greene, C., Rysman, M., Schuh, S., \& Shy, O. (2014). Costs and Benefits of Building Faster Payment Systems: The U.K. Experience and Implications for the United States. Current Policy Perspectives, No. 14-5, 1 - 48. Available from: https://www.bostonfed.org/economic/current-policy-perspectives/2014/cpp1405.pdf.

Gumbo, V., \& Zoromedza, C. (2016). Bank Failure Prediction Model for Zimbabwe. Journal of Applied Economics and Finance, 3(3) Retrieved from http://redfame.com/journal/index.php/aef/article/view/1639/1677. http://dx.doi.org/10.11114/aef.v3i3.1639

Hansnaoui, A., \& Freeman, I. (2010). Diffusion and Implementation of Corporate Social Responsibility (CSR): The Role of Information and Communication Technologies (ICT). Revenue Management \& Avenir. 9(39), 385-406. Retrieved from http://www.cairn.info/revue-management-et-avenir-2010-9-page-386.htm.

Ishad, C. V. (2014). Keynesian Theory of Liquidity Preference Retrieved from http://icv.hubpages.com/hub/Keynesian-Theory-of-Liquidity-Preference.

Jefferis, K., Chigumira, G., \& Chipumho, E. (2013). A Review of Zimbabwe's Optimum Future Currency Regime'. Zimbabwe Economic Policy Analysis and Research Unit. Available: from: http://elibrary.acbfpact.org/acbf/collect/acbf/index/assoc/HASHc812.dir/doc.pdf.

Jenkins, B. (2008). Developing Mobile Money Ecosystems. Retrieved from https://www.hks.harvard.edu/m-rcbg/papers/jenkins_mobile_money_summer_008.pdf.

Jerome, N. (2013). Application of the Maslow's hierarchy of need theory; impacts and implications on organizational culture, human resource and employee's performance. International Journal of Business and Management Invention, 2(3), 39-45. Retrieved from https://www.researchgate.net/file.PostFileLoader.html

Johnson, R. B., Onwuegbuzie, A. J., \& Turner, A. L. (2007). Toward a Definition of Mixed Methods Research. Journal of Mixed Methods Research, 1(2), 112-13. Retrieved from

http://drupal.coe.unt.edu/sites/default/files/24/59/Johnson,\%20Burke\%20Mixed\%20Methods\%20Research.pdf. http://dx.doi.org/10.1177/1558689806298224

Johnston, S. (2011). Infographic: Diffusion of Social Networks. Retrieved from https://samj.net/2011/11/10/infographic-diffusion-of-social-networks-facebook-twitter-linkedin-and-google/.

Kabweza, L. S. M. (2014). NetOne by the numbers: $2.7 \mathrm{mil}$ subscribers, 200k OneWallet subs, $\$ 105 \mathrm{M}$ revenue. TechZim Technologies. 24 June. Retrieved from www.techzim.co.zw/2014/06/netone-by-the-numbers/.

Kufandirimbwa, O., Zanamwe, N., Hapanyengwi, G., \& Kabanda, G. (2013). Mobile Money in Zimbabwe: Integrating Mobile Infrastructure and Processes to Organisation Infrastructure and Processes. Online Journal of Social Science Research, 2(2), 92-110. Retrieved from http://www.onlineresearchjournals.org/JSS.

Lancaster, H., \& Lange, P. (2015). Zimbabwe Telecoms Mobile and Broadband Market Insights and Statistics. Retrieved from www.budde.com/au/research/zimbabwe-telecoms.

Macheka, T. (2014). Zim's PDL too high - Mangudya. The Zimbabwe Mail. Retrieved from http://www.thezimmail.co.zw/2014/11/18/zims-pdl-too-high-mangudya/.

Marsden, P. (2013). Digital at Point of Sale: Reinventing Retail for the Connected Customer. Retrieved from http://www.syzygy.de/media/21462/syzygy_whitepaper_digital_pos.pdf.

Meerapur, A. (2014). Online Transaction Processing (OLTP). Retrieved from http://www.studymode.com/essays/Online-Transaction-Processing-Oltpthe-Following-Is-65509396.html.

Munyanyi, W. (2014). Banking the unbanked: Is Financial Inclusion Powered by Ecocash a veracity in Rural Zimbabwe. Greener Journal of Banking and Finance. 1(1), 001-009. Retrieved from http://gjournals.org/GJBF/GJBF\%20PDF/2014/February/112013975\%20Munyanyi.pdf4 .

Nwankwo, O., \& Eze, O. R. (2013). Electronic Payment in Cashless Economy of Nigeria: Problems and Prospect. Journal of Management Research, 5(1), 138-151. Retrieved from www.macrothink.org/journal/index.php/jmr/article/download/2650/2434. 
OK Zimbabwe. (2015). Who is OK Zimbabwe Limited? Retrieved from http://www.okziminvestor.com/.

Olatokun, W. M. (2011). Integration of Policies and Regulatory Frameworks for the Convergent ICT Industry in Nigeria. In B. D. Medlin, H. Geray, H. K. Chavula, L. A.Mohammed, P. Shields \& S. Venkatraman (Eds.), Handbook of Research on Information Communication Technology Policy: Trends, Issues and Advancements. Retrieved from http://www.igi-global.com/chapter/integration-policies-regulatory-frameworks-convergent/45400.

Organisation for Economic Co-operation and Development. (2002). Reviewing the ICT sector definition: Issue for discussion. Retrieved from http://www.oecd.org/dataoecd/3/8/20627293.pdf.

Padoa-Schioppa, T. (2003). A Glossary of terms used in payments and settlements systems. Retrieved from: http://www.bis.org/cpmi/publ/d00b.pdf .

Pikkarainen, T., Pikkarainen, K., Karjaluoto, H., \& Pahnila, S. (2004), Consumer acceptance of online banking: an extension of the technology acceptance model. Internet Research, 14(3), 224-235. Retrieved from: http://www.researchgate.net/profile/Heikki_Karjaluoto/publication/220146845. http://dx.doi.org/10.1108/10662240410542652

Rogers, E. M. (1995). Diffusion of innovations. (4 ${ }^{\text {th }}$ ed.). New York, NY: Free Press.

Rouse, M. (2011). What is a Point-of-Sale Terminal (POS Terminal)? Retrieved from http://whatis.techtarget.com/definition/point-of-sale-terminal.

Saungweme, T., Matsvai, S., \& Sakuhuni, R. C. (2014). Econometric Analysis of Unemployment, output and growth of the Informal Sector in Zimbabwe (1985-2013). International Journal of Economics and Research, 2(4), 1-9. Retrieved from http://www.ijeronline.com/documents/volumes/Vol 5 iss 02/ijer v05 i2(1).pdf.

Shambare, R. (2013). Technology readiness and EFTPoS usage in Zimbabwe. International Journal of Business and Economic Development, 1(1), 13-33. Retrieved from http://ijbed.org/admin/issue/pdf/volume_12345/2.pdf.

SPAR Zimbabwe (2015).Our History. Retrieved from http://spar.co.zw/about-us/.

Tashakkori, A., \& Teddlie, C. (2003). The Past and the Future of Mixed Methods Research: From 'Methodological Triangulation' to 'Mixed Methods Designs'. In Tashakkori, A. and Teddlie, C. (eds.). Handbook of Mixed Methods in Social and Behavioral Research. Thousand Oaks: Sage Publications. Retrieved from http://www.sagepub.com/sites/default/files/.

TM Zimbabwe. (2014). About TM Supermarkets. Retrieved from www.tmsm.co.zw/TM_supermarkets.htm.

The Daily News (2014). Monthly consumer basket decreases. May 22 . Retrieved from https://www.newsday.co.zw/2014/05/22/monthly-consumer-basket-decreases/.

Tyler, W. M. (2007). Point-of-Sale: A beginners Guide to Computerised POS Software. Retrieved from http://www.abs4pos.com/files/HowtobuyaPOS.pdf.

Yonck, R. (2010). The age of the interface. The Futurist, 44(3), 14-19. Retrieved from http://intelligent-future.com/wp/articles/Interface.pdf.

Zimswitch Technologies. (2013). Online Payments. Retrieved from http://www.zimswitch.co.zw/

\section{Copyrights}

Copyright for this article is retained by the author(s), with first publication rights granted to the journal.

This is an open-access article distributed under the terms and conditions of the Creative Commons Attribution license which permits unrestricted use, distribution, and reproduction in any medium, provided the original work is properly cited. 